\title{
Recognizing Crisis in Culture
}

\section{Zofia Rosińska}

The main problem I will consider is the question of the possibility of recognizing a crisis in culture. By recognition I mean the cognitive intuition that paves the way for subsequent stages of knowledge, i.e., the distinguishing of a given phenomenon as different and separate and its identification as a crisis. Crisis here is to be understood as a transitional state, a dramatic upturn in axiological structure. Manifestations of crisis recognition were present already in Antiquity and I will discuss some examples in my talk. I will argue that such recognition is possible owing to the resonant structure between the goings on in culture and goings on within ourselves. The analysis of the phenomenon will be carried out on the basis of the ideas of two authors: Witkacy, an artist and philosopher, and Stefan Morawski, a philosopher of culture and aesthetician.

Keywords: recognition, culture, crisis, uprootedness, values, vital resonance

The category of "recognition" is not frequently analysed in philosophy, although this common experience is a phenomenon often described in literature. Let us recall that it was the dog Argos that first recognized his master. "As soon as he saw Ulysses standing there, he dropped his ears and wagged his tail, but he could not get close up to his master"1. In Poetics, Aristotle defines recognition (anagnorisis) as a "change from ignorance to knowledge" . Furthermore, the Polish word for recognition (rozpoznanie) compels us to assume that we in fact possess some knowledge prior to becoming ignorant, which would make the entire process actually consist of three stages. In order to recognize somebody or something, one must have known that person or thing before.

ZOFIA ROSIŃSKA, Professor Dr. Habil., Department of Philosophy, University of Warsaw, Poland; address for correspondence: Department of Philosophy, ul. Krakowskie Przedmieście 3, 00-047 Warszawa, Poland. E-mail: z.w.rosinska-zielinska@uw.edu.pl

${ }^{1}$ Homer, The Odyssey, trans. S. Butler, bk. XVII,classics.mit.edu [accessed 20 April 2016].

${ }^{2}$ Aristotle, Poetics, trans. S. H. Butcher, pt. XI, classics.mit.edu [accessed 20 April 2016]. 
We recognize people and objects by way of noticing gestures, signs, symbols, scents etc., which is described in depth by Paul Ricouer in the book The Course of Recognition ${ }^{3}$.

In the preface to his book Paul Ricoeur wrote that there is no philosophy of recognition. Six years later (2010) we saw the publishing of The Philosophy of Recognition, a book containing a dozen or so articles devoted to recognition. In the introduction we read that "[t]he theory of recognition is now a wellestablished and mature research paradigm in philosophy"4. This publication presents approaches to recognition adopted within critical theory and Hegelinspired socio-political philosophy. "The theory of recognition [...]" the introduction continues, "[...] has now come into its own as a scholarly framework, to a large part due to the integrative accomplishments of Axel Honneth's theory"5.

As Ricoeur has shown by analysing all types of dictionaries, however, the category of "recognition" has more meanings than Hegel's "Anerkennung", to which the above authors refer, although there can be no doubt that "a struggle for recognition" has become today not only an important cultural experience, but also a dominant subject in social and political philosophy.

In this paper I would like to draw attention to recognition understood not as "a struggle for recognition", but as identification - "to recognize" somebody or something would thus mean "to identify that person or thing".

How is it possible, however, to recognize crisis?

I shall illustrate the way in which this question could be answered by discussing ideas developed by Stanisław Ignacy Witkiewicz (Witkacy) and Stefan Morawski. Neither of them writes explicitly about recognizing the crisis - they speak of its presence.

Morawski, who was my teacher, would be ninety-four years old now if he lived today. An extraordinary erudite, he traced the topos of crisis in culture and art both in history and in contemporary reality, i.e. the $20^{\text {th }}$ century. His last study on this subject is the 1999 book titled Unrewarding drawing of a map (Niewdzięczne rysowanie mapy) ${ }^{6}$. Analysing, interpreting and classifying diverse positions assumed by philosophers and artists on the subject of crisis in culture,

\footnotetext{
${ }^{3}$ P. Ricoeur, The Course of Recognition, trans. D. Pellauer, Harvard University Press, Harvard 2007.

${ }^{4}$ The Philosophy of Recognition. Historical and Contemporary Perspectives, ed. by H. - Ch. Schmidt am Busch, Ch. F. Zurn, Lexington Books, Plymouth 2010, p. 1.

${ }_{6}^{5}$ Ibidem, p. 4.

${ }^{6}$ S. Morawski, Niewdzięczne rysowanie mapy...: o postmodernie(izmie) i kryzysie kultury, Wydawnictwo Uniwersytetu Mikołaja Kopernika, Toruń 1999.
} 
he concludes (not explicitly but it clearly emerges from his research) that crisis, though its symptoms vary, is a permanent element of European culture. This raises questions regarding the character and specificity of European culture, for it facilities or generates crises, but nevertheless retains its identity.

Witkacy was a truly remarkable and multidimensional figure: artist, painter and philosopher. Knowledge about his life and work should become common intellectual good in the entire sphere of European culture. An adherent of metaphysical anxiety, he attacked philosophical minimalism, pragmatism and the programme of the Vienna Circle. In art, he advocated pure form. If he were alive today, he would be one hundred and twenty years old. In a discussion of the possible interpretations of the formula of "the twilight of art", Morawski wrote about Witkacy that "he was the first to argue that we deal not only with the twilight, but also the death of art. It was not just a reaction of a rebellious artist [...] for his arguments were grounded in specific philosophical premises"7. Finally, Morawski hailed him as an "incredible phenomenon" and compared him to Martin Heidegger.

Morawski and Witkacy differ not only in terms of their philosophical character and the scope of their work, but also - above all - in their methodology. Morawski works in the horizontal dimension, i.e. he enters an already existing discourse on crisis. He characterizes it, raises critical questions and presents his own convictions, thus initiating an intellectual dialogue on this subject.

Witkacy, on the other hand, works in the vertical dimension, i.e. he relies on his "metaphysical experiences" and makes them the basis of his reflection on crisis. Thus, he compels us to enquire about the role of personal experience in the process of recognizing crisis. Particular acts of recognition can be more easily pointed out in works by Witkacy rather than in Morawski. This does not mean, however, that they cannot be discerned in the latter's oeuvre.

The crucial question is whether there is crisis, what would it consist of and how do we learn about it, i.e. what are the conditions of the possibility to recognize it. In my opinion, recognition is a cognitive premonition that paves the way for discerning and identifying a certain phenomenon as crisis.

${ }^{7}$ Idem, Na zakręcie: od sztuki do po-sztuki, Wydawnictwo Literackie, Kraków 1985, p. 288. 
Early instances of recognizing crisis in culture can be found in antiquity. The Book of Isaiah contains the following passage about Jerusalem: "How is the faithful city become an harlot! It was full of judgment; righteousness lodged in it; but now murderers. Thy silver is become dross, thy wine mixed with water: Thy princes are rebellious, and companions of thieves: every one loveth gifts, and followeth after rewards: they judge not the fatherless, neither doth the cause of the widow come unto them"s.

In Thucydides we read: "[...] as the disaster passed all bounds, men, not knowing what was to become of them, became utterly careless of everything, whether sacred or profane. All the burial rites before in use were entirely upset, and they buried the bodies as best they could. Many from want of the proper appliances, through so many of their friends having died already, had recourse to the most shameless sepultures: sometimes getting the start of those who had raised a pile, they threw their own dead body upon the stranger's pyre and ignited it; sometimes they tossed the corpse which they were carrying on the top of another that was burning, and so went off.

Nor was this the only form of lawless extravagance which owed its origin to the plague. Men now coolly ventured on what they had formerly done in a corner, and not just as they pleased, seeing the rapid transitions produced by persons in prosperity suddenly dying and those who before had nothing succeeding to their property. So they resolved to spend quickly and enjoy themselves, regarding their lives and riches as alike things of a day. Perseverance in what men called honour was popular with none, it was so uncertain whether they would be spared to attain the object; but it was settled that present enjoyment, and all that contributed to it, was both honourable and useful. Fear of gods or law of man there was none to restrain them. As for the first, they judged it to be just the same whether they worshipped them or not, as they saw all alike perishing; and for the last, no one expected to live to be brought to trial for his offences, but each felt that a far severer sentence had been already passed upon them all and hung ever over their heads, and before this fell it was only reasonable to enjoy life a little",.

In the $4^{\text {th }}$ century BC Demosthenes - the greatest orator of independent Greece - says in the speech »On the Crown« that: "[...] the states were diseased; one class in their politics and measures being venal and corrupt, while the

\footnotetext{
${ }^{8}$ Isaiah 1: 21-23 (King James Version).

9 Thucydides, The History of the Peloponnesian War, trans. R. Crawley, ch. VII, classics.mit.edu [accessed 20 April 2016].
} 
multitude of private men either had no foresight, or were caught with the bait of present ease and idleness; and all were under some such influence, only they imagined each that the mischief would not approach themselves, but that by the peril of others they might secure their own safety when they chose" ${ }^{10}$.

There also exists a different account of an extreme situation, which reveals the power of the spirit: "We knew what brotherhood is. Brotherhood means identifying with others, tying one's own fate with that of the other; moreover, it entails seeing his or her danger more clearly than one's own. It is a feeling that a comrade's death is more difficult to bear than one's own. Brotherhood is the ease of transcending those boundaries that the philosophers who advocate human loneliness consider to be impassable. Beyond those boundaries, they claim, there is only silence or the echo of one's own voice. We, on the other hand, were deep inside the word $» w e \ll-$ a word that phenomenologists view as denoting a special quality of experience, which shapes the perception of the world and imparts a different dimension of existence to us [...] if we are a part of that circle and feel hungry - hunger being one of the faces of danger - then we reach out our hands for bread so as to give it to others. We are as much afraid of our own hunger as we are afraid of the hunger of others [...] we do not act in this way because doing so is the highest value; we are this value and without such gestures our brotherhood circle would be broken"11.

Why is it so that in some people, probably even the majority, extreme situations (e.g. a plague in Greece) reveal the weakness of spirit, while in others - its power (e.g. in a concentration camp)? This question will probably have to remain unanswered. As Jan Strzelecki rightly claims, "by initiating us into the cruellest mechanism of the so-called history and revealing how low can men fall, we are also taught about the creative potential of people subjected to the hardest of trials" $" 12$.

\footnotetext{
${ }^{10}$ Demosthenes, On the Crown, trans. C. R. Kennedy, bartleby.com [accessed 20 April 2016].

${ }^{11}$ J. Strzelecki, Kontynuacje (2), Państwowy Instytut Wydawniczy, Warszawa 1974, p. 13-14.

${ }^{12}$ Ibidem, p. 1.
} 
Crisis is a period, or temporary state, from which we emerge healthy or sick, mature or infantile, rich or poor etc. However, in many cases - and not only in popular understanding - crisis is equated with worsening. Thus, when speaking about crisis we assume, perhaps not entirely consciously, the existence of a certain positive status quo, which could be defined (depending on the philosophical concept of humanity) as happiness, completeness, rationality, prosperity, wisdom, justice, community etc. Such a status quo could be located in the past or in the future. It could be a utopia or a dystopia.

I share Morawski's belief that crisis - understood in the above sense has been present in European culture for ages. It surfaces cyclically and is accompanied by counter-crises. The phrase "for ages" is not a strong claim here, for it has been neither historically proven nor confirmed by anthropological studies. It is a weak claim, which should be understood only as an observation that there are traces of the experience of crisis in the earliest sources of European culture, i.e. in the Bible and in ancient Greek texts. The category of "experience" is crucial here, for it expresses the view that in philosophical considerations of culture we do not encounter "cultural facts" apprehended through a priori concepts, but rather deal with "a thinking that is saturated with the world" or - to put it in Aristotelian terms - "the philosophy of human concerns". This is "mondo civile", as Vico put it, and not an objective knowledge of culture, which would be independent from humankind. The thinking that is saturated with the world does not have a stable character and is rather mobile, dynamic and changeable. Therefore, its central category cannot consist of a fixed definition.

Most people who find themselves in a radically critical situation are not even aware of the crisis. This is aptly illustrated by the following parable, anecdote or story recounted by Kierkegaard: "In a theatre, it happened that a fire started offstage. The clown came out to tell the audience. They thought it was a joke and applauded. He told them again, and they became still more hilarious. This is the way, I suppose, that the world will be destroyed - amid the universal hilarity of wits and wags who think it is all a joke"13. Did the people not listen to the clown because they were convinced he could not speak seriously? Do we not have any doubts regarding our convictions?

Martin Heidegger argues that the origin of crisis lies in technology. Its manifestation is uprootedness: "according to our human experience and history,

${ }^{13}$ S. Kierkegaard, Either/Or, Part I, trans. H. V. Hong, E. H. Hong, Princeton University Press, Princeton 1987, p. 30. 
everything essential and of great magnitude has arisen only out of the fact that man had a home and was rooted in a tradition [...] technicity increasingly dislodges man and uproots him from the earth. [...] The uprooting of man is already here" 14 . However, technology can be considered to be not only the root of crisis but also the driving force behind progress. Did Heidegger consider uprootedness to be a symptom of crisis because he valued tradition so much?

There are numerous reasons why we fail to recognize crisis. Erich Fromm who characterized the decadent crisis, i.e. the one described as malaise, ennui, mal du siècle, loss of vitality, automatization of man, alienation from oneself, neighbour and nature - noticed that although crisis is not felt by the general public, "there is agreement, at least among a number of critical observers, as to the existence and the nature of this crisis"15.

What does he mean by "critical observers"? Kierkegaard suggests that one should "Take what comes and avoid all complications"16. If we rejected his irony and gave this statement serious thought, would we be really able to recognize crisis? Critical observers cannot simply "take what comes" - they have to judge, discern, identify and assess. Recognition is not the same thing as cognition, sinceit constitutes a preliminary stage - a pre-cognitive one that guides later cognition. In Diapsalmata Kierkegaard confesses: "I take problems on my nose"17. Such a metaphorical expression facilitates numerous interpretations. One counterpart to the nose could be intuition or sensory perception. However, both perception and intuition have been already acknowledged, described and characterized in philosophy as cognitive powers related to the knowledge that we already possess. So, "taking on the nose" seems to be the capacity to recognize. It is an "axiological magical wand" which allows us to conduct a reconnaissance of the axiological field, i.e. to judge, discern, identify and assess. The axiological wand allows the observer to remain critical -to detect the crisis and establish its nature. However, someone who treats technology as a source of progress also judges, discerns, identifies and assesses. Such people could also be called critical observers. It is the category of "ideology" that imposes itself here as responsible for qualifying and judging the same phenomenon as crisis or progress. Still, although ideological convictions play their role here, they do not offer a complete answer. We have to assume

${ }^{14}$ M. Heidegger, Only a God Can Save Us, trans. W. Richardson, [in:] Heidegger: The Man and the Thinker, ed. by T. Sheehan, Precedent Publishing Company, Chicago 1981, p. 56-57.

${ }^{15}$ E. Fromm, Zen Buddhism and Psychoanalysis, Harper \& Brothers, New York 1960, p. 78.

${ }^{16}$ S. Kierkegaard, Either/Or, Part I, op. cit., p. 33.

${ }^{17}$ Ibidem, p. 36. 
that there exists in our mind an axiological structure that is shaped by culture, a structure that allows us to recognize, discern and identify particular phenomena, and judge them to be symptoms of crisis.

Crisis can emerge in various domains of culture: art, economy, mores, morality, psychology and science. The common ground for all types of crisis despite the fact that their manifestations or symptoms can be quite diverse is the area of axiology. No crisis occurs without an axiological

\section{transformation, understood as a change in the hierarchy of values.}

However, let us recall, following Roman Ingarden, that values have no existence of their own. They are always attached to an object they belong to. In other words, values have their carriers, which can include people and their actions, or material objects, e.g. works of art. Reinforcement of values consists in realizing them. There are different ways of doing so, just as there are different ways of responding to values, ranging from fanaticism to nihilism. When Ingarden spoke about values in the 1960s, he had no doubt that moral values stand above the aesthetic ones in the overall hierarchy. Their mode of existence is different. He wrote explicitly that moral values "demand" to be realized, while aesthetic ones just "ask". In his opinion, moral values cannot be equated with aesthetic, pragmatic and truth-related ones. Such identification is prevented by the dignitas inherent in moral values. The paper that Ingarden delivered in Krakow, Belgradeand Sarajevo is titled What we do not know about values $\left(\right.$ Czego nie wiemy o wartościach ${ }^{18}$. My aim here is not to analyse this paper in detail. However, I wish to draw attention to the shift in axiological awareness.

Fifty years later, we are dealing with an attempt to change the hierarchy of values. The dignitas of moral values has been somewhat obscured, which is confirmed by attempts to aestheticize life, i.e. to turn life into art and focus primarily on pleasure. I would say that the phenomenon of transforming the axiological hierarchy could be called crisis. As values come into conflict, we cannot be certain which ones will emerge victorious. The axiological wand not only allows us to recognize this process, as well as the strength or weight of values, but also indicates the side on which others engage in it. When Jean Baudrillard writes about the unlimited freedom to choose one's mask and passion, diagnosing it as a suicidal strategy, or when Bauman speaks of adiaphorization, i.e. callous moral indifference disguised as beautification of the world, we can have no doubt that the dignitas of moral values is firmly

${ }^{18}$ R. Ingarden, Czego nie wiemy o wartościach, [in:] R. Ingarden, Przeżycie, dzieło, wartość, Wydawnictwo Literackie, Kraków 1966, p. 83-128. 
established in these thinkers. Stephen Frosh, a psychiatrist and psychologist from the University of London, wrote in 1991 that one commonly acknowledged property of the contemporary mind is that it is unable to struggle to be itself. He adds that contemporary culture breaks away from the past, as well as rejects tradition and its former assumptions, undermining old ideas and ways of establishing relations between people, or between people and things. Thus, he concludes, the question of the self becomes central ${ }^{19}$. There is no doubt that Frosh's account has an axiological character.

What is this wand, which allows us to recognize changes in the axiological field and thus detect crises? Is it something like "taking on the nose"? We have little idea as to how it operates. However, it seems impossible to sense things with something that has no capability of sensing. How did Argos recognize Ulysses? Perhaps by the smell he remembered and recognized. Recognizing crisis - i.e. detecting changes in culture - demands from the recognizing party a lot more than just a sense of smell. The axiological wand, or the ability to recognize, compels us to assume the existence of a dynamic, multipartite concept of the mind. Plato postulated this in Book IX of The Republic, where he mentions that in every man there are unlawful pleasures and lusts, which are brought under control by rational laws and desires. The former are "are awake when the reasoning and human and ruling power is asleep [...]" for "[...] in all of us, even in good men, there is a lawless wild-beast nature, which peers out in sleep" 20 .

Sigmund Freud also analysed this concept. Albert Camus agreed with him when he wrote that: "We all carry within us our places of exile, our crimes and our ravages. But our task is not to unleash them on the world; it is to fight them in ourselves and in others" 21 . Camus's imperative to combat one's own destructive powers, and Plato's demand to establish control over them could be interpreted as the result of recognition and subsequent decision to become engaged on a particular side. In this way, recognition and engagement precede cognitive activity.

Morawski traces the European topos of crisis in culture. He understands crisis as a "radical undermining of the kind of social order that has been

\footnotetext{
${ }^{19}$ S. Frosh, Identity Crises. Modernity, Psychoanalysis and the Self, MacMillan, London 1991, p. 35 .

${ }^{20}$ Plato, The Republic, trans. B. Jowett, bk. IX (572b), classics.mit.edu [accessed 20 April 2016].

${ }^{21}$ A. Camus, The Rebel: An Essay on Man in Revolt, trans. A. Bower, Vintage Books, New York 1984, p. 301.
} 
preserved so far" 22 . It is a shock that engulfs the entire axiological structure, demolishing its foundations, which we have grown accustomed to and consider inviolable, and forcing us to revise the paradigm that we have considered to be self-evident, with values changing their importance. "Such things take place in front of our eyes and within ourselves" ${ }^{23}$. This sentence becomes crucial for reflection on recognition. It emphasises a vital resonance, or analogy between that which happens inside us and the changes in culture. After all, there is no man without culture. The things that happen inside us facilitate the recognition of what happens outside us, in culture, ultimately allowing us to recognize crisis. We encounter here the hermeneutic principle that "we recognize things through those that are alike", which was formulated by Empedocles and developed by Wilhelm Dilthey, who spoke of recreating another person's life in the process of understanding and claimed it to be possible because we share a "common human nature": "all individual differences are, in the last resort, conditioned not by qualitative differences between people but by differences of degree in their mental processes $[\ldots]$ the interpreter can momentarily emphasise and strengthen some mental processes and allow others to fade into the background and thus reproduce an alien life in himself' 24 . These are the mechanisms that allow the axiological wand to function, i.e. to sense and detect crisis. Ultimately, the possibility of crisis exists within us. All disintegration begins with men: just like there is no culture without man, there is no man without culture. Hans Georg Gadamer's concept of Vorurteil (pre-judgment) also reinforces the kind of approach to recognition that treats it as a pre-verbal and pre-epistemological process, which is nonetheless possible thanks to the individual's rootedness in culture (not always a conscious one), because being ingrained in culture helps us form pre-judgments.

The last sentence quoted from Morawski is rather accidental in the context of his philosophy, which can be generally considered rational and analytical. His reflection on crisis does not begin with recognizing one, but starts from the study and analysis of already existing descriptions of crises. However, his metareflection on the question of crisis encompasses not only a neutral presentation, but also an assessment that is rooted - to my mind - in recognition facilitated by pre-judgments. Morawski steps outside his own methodology and thus lays bare his own axiological structure, which triggers his recognition of crisis.

\footnotetext{
${ }^{22}$ Morawski S., Niewdzięczne rysowanie mapy..., op. cit., p. 282.

${ }^{23}$ Ibidem, p. 284.

${ }^{24}$ W. Dilthey, The Development of Hermeneutics, [in:] W. Dilthey, Selected Writings, ed. \& trans. H. P. Rickman, Cambridge University Press, Cambridge 1976, p. 258.
} 
Morawski claims that the world of culture is axiologically marked. "For us, human beings, there exists nothing that would be impervious to values. Our existence shapes culture and is dependent on it, forming an organic bond that we have come to call civilization" 25 . In contrast to culture, civilization favours values that are material, pragmatic, technological or institutional. Crisis may be provoked when civilization claims to take precedence over culture. Agreeing with Reinhart Koselleck, Morawski claims that the awareness of crisis - whether acute or vague - dates back to the end of the $18^{\text {th }}$ century. What we call postmodernism today - and consider a critical state - has its roots in the Enlightenment. It was already at this point in history that dystopias were created, drawing our attention not to the happiness guaranteed by progress in science and subduing nature, but rather to the negative effects of the growth of civilization, among which are alienation and lack of spontaneity. Nevertheless, Morawski argues that the idea of crisis ripened only towards the end of the $19^{\text {th }}$ century. Oswald Spengler's Untergang des Abendlandesmarks the moment when the successes achieved by civilization initiated the modern process of disintegrating values.

Morawski distinguishes four categories of answers to the question regarding the roots of crisis in culture, which were formulated before 1945:

1) naturalism (Adams, Freud), or the belief that crises are sparked by factors operating outside culture, e.g. biological or physical ones;

2) commodification of social life, or the mechanization of human relations, as well as the homogenization of needs, and state control (Witkacy, Znaniecki, Ortega Y Gasset, Huizinga);

3) axiological elevation of scientific reason and the privileging of pragmatic values (Husserl, Jaspers, Heidegger);

4) downfall of the authority of faith (Leibniz, Berdyaev, Zdziechowski, Maritain).

The above ailments, identified as responsible for triggering crisis, were met with counter-crisis reactions. Morawski enumerates some of them: emergence of subcultures and alternative forms of existence; intensifying of religious attitudes (i.e. realizing that without transcendence we are robbed of the mystery of our own existence) as well as revisiting basic philosophical questions; return to nature (e.g. carnality, spontaneity and authenticity), including revolutions in sexuality and mores; finally, developing of cultural projects that focus on the active (Jerzy Grotowski) and the innate (Centre for Theatre Practices

\footnotetext{
${ }^{25}$ Morawski S., Niewdzięczne rysowanie mapy..., op. cit., p. 280.
} 
"Gardzienice"). The aim of these reactions was to overcome stereotypes and conventions, as well as struggle to differ and find original roads to transcendence. Finally, there were attempts to establish communes, where people were supposed to perceive human relations not in terms of competition but participation. Ultimately, what may be intuitively regarded as crisis in itself would become in this light a symptom of a deeper crisis in culture, which we are able to identify through pre-cognitive resonance - the connection between culture and the self.

Morawski places particular emphasis on one trend that dominated in the 1960 s, i.e. the gadgetization of man and his relations with others. The civilization-related imperialism impoverishes the values that European culture considered to be of the highest order: spontaneous expression, intimate contacts and - as Morawski puts it - "that mysterious remainder" which cannot be rationally explained. This was supported by transformations in education, which dissociated the transmission of knowledge from the deeper formation of character. It is the latter process that, according to Johann Gottfried Herder, "shapes people into human beings".

Those changes were recognized and revealed in numerous works, bringing into existence the so-called anti-crisis topos. According to Morawski, the most insightful and extensive analyses in this area were offered by Baudrillard. Moreover, he also recounts the importance of the 1968 student protests and the Second Vatican Council. Following numerous discussions on the question of crisis, Morawski does not underestimate works by those scholars (e.g. Francis Fukuyama) who do not recognize any crisis and consider such deliberations as anachronistic and ridiculous. They claim, for example, that economic growth is harmonized with ecology and no catastrophes await us in the future. What is more, they argue that people's basic needs, such as stabilization and security, are in fact being satisfied. This picture could be completed by observing that Fukuyama leaves no room for "metaphysical hunger". Morawski concludes his survey of recognitions by arguing that "we should also become aware [...] that our condition is aporetic, i.e. there are no ideal entrances and exits. Evil is mixed with good, and vice versa. Freedom and equality do not form a necessarily harmonious and indissoluble pair. The more of the former, the less of the latter or the other way round [...]. It is wrong when private property takes precedence over the sense of justice, but it is equally wrong when this kind of property is being eliminated [...]. The list of such aporetic knots could be easily expanded. For example, it is not desirable for mass culture, which often borders on kitsch, 
to absorb high art, but at the same time it is impossible to depreciate popular culture in one sweeping gesture. After all, it expresses people's fundamental needs and, by distancing itself from artistic priesthood, healthily ridicules the pretentious and vain. Moreover, mass culture has inspired carnivalesque performances and many avant-garde ideas" 26 .

Is the conviction about the aporetic nature of the human condition a consequence and rational culmination of studies on crisis, or is it a manifestation of having recognized the crisis that characterizes the end of the $20^{\text {th }}$ century (the moment when Morawski reflected on crisis in European culture)?

It also remains an open question why Morawski did not take into consideration the ideas developed by Emmanuel Lévinas, who identified the source of the European crisisto be its philosophical tradition, which is responsible for the immanent character of this culture. European tradition could be understood as one that homogenizes and interiorizes that which is different. The philosophical roots of the homogenizing and thus totalizing approach lie - according to Lévinas - in the thought of Parmenides. The homogenization and totalization of culture and world are the consequence of having assumed that our sole, primordial and fundamental relation with the world has a cognitive character, i.e. it consists of the desire to make the world intelligible and turn it - both in theory and practice - into something absolutely transparent and comprehensible. The realization of that desire was facilitated by cutting off the Judaic root of European culture - one that emphasised the alterity of the other and the importance of moral contact understood, unlike the intellectual approach, as the absolute basis and foundation. Within a moral relationship, the ego does not think "about" but rather "for".

However, both the thesis about the aporetic nature of human existence and the abandonment of Lévinas's proposition can be considered to have entailed a preliminary recognition. We should remember that (at least in the Polish language) the verb "to recognize" (rozpoznać) means to identify something as an already known being. Gadamer's concept of "pre-judgments" is very helpful in this context. For example, Morawski's Bildung was structured by the communist regime in a country where communism had not been fully interiorized. Therefore, his mind had to absorb the aporias of everyday life. Those aporias "inside him" allowed him, in turn, to recognize the aporetic nature

\footnotetext{
${ }^{26}$ Ibidem, p. 312.
} 
of human existence. Perhaps we may be dealing here with - as Kierkegaard put it by characterizing genius - "the unity of things that belong to each other".

I would like to illustrate my argumentation with the following excerpt from Morawski's biography: "Thanks to the Rockefeller stipend, I spent two years in Bellagio, where I was writing a study on the manifestations of crisis in culture. What particularly struck me there was that - as I descended to town from the castle where the foundation had its seat- despite the ubiquity of television and other media people still lived according to their own cultural rhythm, which remained close to the exceptional beauty of nature in those parts. Is it not the case that also in Poland, with postmodernism knocking on our doors, there is strong resistance to it" ${ }^{\prime 27}$.

Although staying in Italy and focusing on academic work, Morawski recognizes the same intellectual aporias which he experienced in the Polish People's Republic, especially during the period of marshal law, when "media could say what they want but we knew the truth". However, I doubt whether our mentality has not in fact changed. I am convinced that the aforementioned resistance ceases to be substantial. Relativizing responsibility, abandoning the hierarchy of values, striving for maximal pleasure as well as being fascinated with a techno-vision have become enticing possibilities of experiencing one's life and the world. The principle proposed by Morawski - "life has to be hard and riddled with failure; it cannot be light as a butterfly" - may find few advocates today. It is a fact, however, that we cannot fathom the possible extent of radiation emitted by the new cultural mutation. Metaphysical hunger may still return, while close observation of daily life allows us to conclude that despite everything there does exist a strong need for rules, principles, order, decency and responsibility - a need for subjectivity and the vertical dimension of culture. Those needs can be fulfilled by philosophy, which Morawski believes to be an "indispensable existential prosthesis", meaning that it "brings values and sense to an imperfect and contingent world" ${ }^{28}$. Understanding philosophy as an existential prosthesis seems to contradict Morawski's vision of philosophers as the leading "trouble makers". Either we endow the world with meaning or pick holes in it, destroying that meaning. According to Morawski, however, there is no contradiction here, since philosophers "do not consent to the status quo": "They stand up for those principles which are thrown overboard, and shatter those which have become petrified [...] philosophising must assume

\footnotetext{
${ }^{27}$ Ibidem, p. 329.

${ }^{28}$ Ibidem, p. 317.
} 
responsibility for degrading the greatest values and boldly confront the crisis of culture" 29 . After all, principles and rules do not always express the most precious values.

I would offer a similar commentary regarding Morawski's failure to recognize Lévinas's concept of the origins of crisis. Morawski could not recognize the French philosopher's answer because his pre-judgments were influenced by the cognitive approach to the world. He had no tools (nor did he revive any) that would allow him to recognize that it is this particular relation to the world that could actually constitute the root of crisis. A citizen in the world of Parmenides, he was unable to - as Dilthey put it - "reproduce an alien life in himself", which is a capability that strongly informs Lévinas's philosophy. Despite the fact that Morawski's methodology is indeed questing and questioning, analogously to Theodor W. Adorno's Selbstkritik der Philosophieits aims are strictly cognitive. In his 1980s book titled From art to post-art (Od sztuki do po-sztuki) he remarks: "I have not tried to settle anything, but rather raised questions and made suggestions that demand historical verification, although this procedure alone cannot answer or verify them completely"30.

Nevertheless, his last work (published in 1999) contains passages that suggest Morawski highly valued not only philosophical and artistic reflection, or the critical and questioning method, but also experience itself. He speaks of existential experiences. Not being a hermeneutic philosopher himself, he introduces a methodologically important distinction within hermeneutics, discerning a primary one, constituted by existential experiences and knowledge contained in them (doxa), and a secondary one, which takes those experiences as its basis, recognizing and interpreting crisis. In other words, doxa or existential experience would facilitate or prevent the recognition of crisis.

However, the question should be raised whether observations made in the 1980s remain valid. Have forces related to the aforementioned tendencies not changed their intensity? Could it be that their effects in the axiological dimension do not differ? It seems, after all, that the counter-crisis activities spawn new crises. By relying on the dynamics of "going beyond", countercultures also cross those norms and rules they meant to defend. This leads to a war waged between two fundamentalisms.

\footnotetext{
${ }^{29}$ Ibidem, p. 318.

${ }^{30}$ Idem, Na zakręcie: od sztuki do po-sztuki, p. 159.
} 
One example of this could be the crisis of morality and mores, which is easily observable today, not only in Europe. A consequence of new technological possibilities, it is primarily related to going beyond the reverence for human life, a value which has been always treasured in culture. What I mean here are the so-called bioethical disputes on euthanasia, abortion, in vitro fertilization and cloning. We are dealing here with a conflict that has been already described in Greek tragedy and philosophically interpreted - namely, the conflict between moral law and state law. As it turns out, the dispute between Antigone and Creon is still topical.

What is the status of art in a culture that fosters crisis?

Morawski claims that no one is able to answer the question of what art is. We can ask, however, whether art must last forever. Can the stimuli, which led to its birth, find another vent? What could we replace the category of "art" with? Morawski considers four possible concepts: "creativity", "exploration", "participation" and "intensified perception". He rejects all four, because each of them is much broader than art. However, they define - according to Morawski the ground on which art emerged. Therefore, he concludes that if we assume art was once born, we can just as well concede that it may eventually disappear. Of course, this is just one possible conclusion. In fact, Morawski enumerates four reasons why art would be irreplaceable: (i) it defamiliarizes the familiar and familiarizes that which is unusual or mysterious; (ii) it grants access to human personality, which is most fully expressed in art; (iii) it records that which is fleeting and ephemeral; (iv) it inspires us to perceive the world in a certain way and ascribe particular values to objects of all kinds. Morawski is well aware that all four above reasons can be questioned. He recalls, for example, his own experience from Krakow, when news reached the people that Cardinal Wojtyła was elected Pope: "The atmosphere on the streets, the singing of students gathered by the Cloth Hall, and the mass in St. Mary's Basilica - no work of art could convey that" ${ }^{\prime 31}$.

By analysing the topos of the twilight of art, Morawski refers to those convictions shared by philosophers and artists, which facilitate consideration or discussion of this theme and - let us add - made it possible to recognize the twilight of art. What they share is an aesthetic paradigm, i.e. the unwritten

\footnotetext{
${ }^{31}$ Ibidem, p. 307.
} 
belief that artists know what they are doing and express themselves thanks to a particular competence in terms of technique. This aesthetic paradigm, culturally established and widely assumed, was the background, or the status quo, that facilitated the recognition of the twilight of art. Without it, the twilight of art, or crisis, would not be recognizable.

According to Morawski, the idea of the twilight of art developed in three stages: the first one was Hegelian, the second led from fin de siècle through Heidegger and Witkacy to Seldmayer, while the third was constituted in the 1950s by the ideological programmes of the neo-avant-garde and the concepts of Adorno, Lukács, Gadamer and Danto. Morawski argues that Witkacy was the first one to speak of the death of art and not just the exhaustion of its meaning. He held that art belongs to the existential and ontological order, which he contrasted with the purely pragmatic, material and technological ones. However, he also maintained that the domination of the material and technological orders leads to the trivialization of aspirations, excessive intellectualization of creative approaches and the abandoning of transcendence in the name of comfort and short-term happiness. People who are open to the mystery of being are becoming extinct. Humankind becomes increasingly brutish and art is marginalized. The death of art entails the death of man - a certain type of man at least. Witkacy sarcastically remarks that people can be happy without metaphysical impulses.

Witkacy developed a philosophical concept of man, which constitutes a philosophical justification of his recognitions. It can be broken down into the following six theses.

Firstly, there is only one existence and it is identical with itself. However, it contains a multiplicity of Particular Existences (always capitalized). Unity in multiplicity constitutes the mystery of being.

Secondly, we can feel the unity of our self. The experienced quality of unity serves as the basis of the metaphysical feeling. Experiencing it directly is also a mystery.

Thirdly, the feeling of mystery breeds many questions: "Why am I this being and not some other one, given that space and time are infinite? Why do I exist among those beings on this particular planet? Why do I exist at all? I could just as well not exist. Why is there anything at all? There could be 
Absolute Nothingness, etc." 32 . These questions can be answered in a scientific way, but we can never elicit a complete answer, for it lies with the Absolute Truth. Religion, philosophy and art are manifestations of this feeling.

Fourthly, the feeling of unity and metaphysical unrest are intensified by contemplation. Witkacy is aware that the state of contemplative focus is not effortlessly accessible for the average person and cannot be easily upheld, for we are usually hard-pressed, distracted and lack time.

Fifthly, the state of the unity of self also occurs in experiences of intense fear, pain or joy. These states, however, differ from contemplative focus in that they leave no room for the awareness of unity, so metaphysical unrest does not surface on those occasions. Those states can evoke metaphysical unrest, but only as a memory, not when they are being experienced.

Sixthly, metaphysical unrest can be felt when falling asleep or waking up, as well as when musing on, for example, the infinity of existence. "This is connected with a sort of annihilation of ourselves in the infinite abyss of the universe, which entails the disappearance of the sense of individual existence through its infinite amplification" 33 .

These quasi-mystical terms do not characterize mystical experiences, however, but rather determine the source from which all creativity flows, especially the artistic one. Art - Witkacy argues - is an "expression of the unity of every Particular Existence and stands opposed to everything that it is not: the whole of Existence". In other words, art is an expression of individuality and forms an opposition to the whole. Witkacy differentiates between superficial (sensual) aesthetic pleasure and the deep one, which is evoked by the sense of unity in multiplicity, stimulating the metaphysical feeling inside us. This, in turn, is the necessary condition for the emergence of an ideal work of art, although this does not mean that other psychological factors are unimportant.

Witkacy visualizes the entirety of psychological spheres in the form of concentric circles. In the very centre we find the metaphysical feeling. The second circle contains life-related feelings and notions. The third one encompasses intellectual matters and controlling forces. Finally, the fourth circle is the sphere of pure forms, i.e. sensual elements (aural, visual etc.). While the metaphysical feeling is identical for all people, other spheres differ from one individual to another. The metaphysical feeling expresses itself through

32 S. I. Witkiewicz, Nowe formy w malarstwie i inne pisma estetyczne, Państwowe Wydawnictwo Naukowe, Warszawa 1959, p. 17.

${ }^{33}$ Ibidem, p. 21. 
the abovementioned circles. They are responsible for articulating multiplicity and diversity, while the metaphysical feeling - for conveying the unity.

The fundamental feature of a work of art is "unity in multiplicity, regardless of what are the elements of that multiplicity and how unity had been achieved. This unity is the beauty of the given work" ${ }^{\prime 4}$.

The category of beauty refers not only to art but also to works that are not art. The difference lies in the fact that in art the expression of the unity in multiplicity is a goal in itself, whereas in other works it is a side effect.

The reception of a work of art lies in grasping unity without prior analysis of the work: "The condition for deep aesthetic pleasure is the impossibility of realizing conceptually why a particular combination of qualities achieves unity" 35 . Preliminary analysis is, however, a necessary stage in the process of teaching the reception of art, and constitutes a transitory stage in apprehending it directly.

On 18 September, one day after the Red Army invaded Poland, Witkacy committed suicide. He recognized that there is no place left for metaphysics anymore.

translated by Grzegorz Czemiel

\section{Bibliography}

Aristotle, Poetics, trans. S. H. Butcher, pt. XI, classics.mit.edu [accessed 20 April 2016].

Camus A., The Rebel: An Essay on Man in Revolt, trans. A. Bower, Vintage Books, New York 1984.

Demosthenes, On the Crown, trans. C. R. Kennedy, bartleby.com [accessed 20 April 2016].

Dilthey W., The Development of Hermeneutics, [in:] W. Dilthey, Selected Writings, ed. \& trans. H. P. Rickman, Cambridge University Press, Cambridge 1976.

\footnotetext{
${ }^{34}$ Ibidem, p. 20.

${ }^{35}$ Ibidem, p. 26.
} 
Fromm E., Zen Buddhism and Psychoanalysis, Harper \& Brothers, New York 1960.

Frosh S., Identity Crises. Modernity, Psychoanalysis and the Self, MacMillan, London 1991.

Heidegger M., Only a God Can Save Us, trans. W. Richardson, [in:] Heidegger: The Man and the Thinker, ed. by T. Sheehan, Precedent Publishing Company, Chicago 1981.

Homer, The Odyssey, trans. S. Butler, bk. XVII, classics.mit.edu [accessed 20 April 2016].

Ingarden R., Czego nie wiemy o wartościach, [in:] R. Ingarden, Przeżycie, dzieło, wartość, Wydawnictwo Literackie, Kraków 1966.

Isaiah 1: 21-23 (King James Version).

Kierkegaard S., Either/Or, Part I, trans. H. V. Hong, E. H. Hong, Princeton University Press, Princeton 1987.

Morawski S., Niewdzięczne rysowanie mapy...: o postmodernie(izmie) i kryzysie kultury, Wydawnictwo Uniwersytetu Mikołaja Kopernika, Torun 1999.

Morawski S., Na zakręcie: od sztuki do po-sztuki, Wydawnictwo Literackie, Kraków 1985.

Ricoeur P., The Course of Recognition, trans. by D. Pellauer, Harvard University Press, Harvard 2007.

Strzelecki J., Kontynuacje (2), Państwowy Instytut Wydawniczy, Warszawa 1974.

The Philosophy of Recognition. Historical and Contemporary Perspectives, ed. by H.-Ch. Schmidt am Busch, Ch. F. Zurn, Lexington Books, Plymouth 2010.

Thucydides, The History of the Peloponnesian War, trans. R. Crawley, ch. VII, classics.mit.edu [accessed 20 April 2016].

Witkiewicz S. I., Nowe formy w malarstwie i inne pisma estetyczne, Państwowe Wydawnictwo Naukowe, Warszawa 1959.

\section{Zusammenfassung}

\section{Die Anerkennung der Krise in der Kultur}

Das erwogene Hauptproblem bildet die Frage nach der Möglichkeit, die Krise in der Kultur zu erkennen. Durch Anerkennung verstehe ich die kognitive Intuition, die den Weg zu weiteren Stufen des Wissens ebnet, d.h. die Unterscheidung fremder, separater Phänomene und ihre Identifizierung als Krise. Die Krise wird hier als eine Übergangsetappe 
begriffen, als ein dramatischer Wechsel in der Wertestruktur. Die Symptome der Krise, deren einige Beispiele im Artikel dargestellt werden, wurden bereits in der Antike erkannt. Ich weise nach, dass eine solche Erkenntnis dank der Existenz einer Resonanz zwischen den Prozessen in der Kultur und den Prozessen in uns selbst möglich ist. Die Analyse des Phänomens führe ich anhand der Überzeugungen von zwei Autoren durch: des Künstlers und Philosophen Witkacy und des Kulturphilosophen und Ästhetikers Stefan Morawski.

Schlüsselworte: Anerkennung, Kultur, Krise, Entwurzelung, Werte, vitale Resonanz

\section{Streszczenie}

\section{Rozpoznawanie kryzysu w kulturze}

Główny rozważany problem to kwestia możliwości rozpoznania kryzysu w kulturze. Poprzez rozpoznanie rozumiem poznawczą intuicję, torującą drogę dla późniejszych stadiów wiedzy, tj. wyróżnienie pewne obcych, odrębnych zjawisk i zidentyfikowanie ich jako kryzysu. Kryzys jest tu rozumiany jako stan przejściowy, jako dramatyczny przewrót w strukturze aksjologicznej. Objawy kryzysu były już rozpoznawane w starożytności; kilka przykładów przedstawię w artykule. Będę wykazywała, że takie rozpoznanie jest możliwe dzięki istnieniu rezonansu między procesami w kulturze i procesami w nas samych. Analizę zjawiska przeprowadzę na podstawie poglądów dwóch autorów: Witkacego - artysty i filozofa oraz Stefana Morawskiego - filozofa kultury i estetyka. witalny

Słowa kluczowe: rozpoznanie, kultura, kryzys, wykorzenienie, wartości, rezonans

Information about Author:

ZOFIA ROSIŃSKA, prof. dr hab., Instytut Filozofii, Uniwersytet Warszawski; adres do korespondencji: Instytut Filozofii UW, Krakowskie Przedmieście 3, 00-097 Warszawa. E-mail: z.w.rosinska-zielinska@uw.edu.pl 